This is the first version of an article whose final and definitive form has been published in the journal Social Identities $($, January 2012 [copyright Taylor \& Francis]; Social Identities is available online at: www.tandfonline.com with an open URL of my article in the following address: $\mathrm{http}: / /$ www.tandfonline.com/openurl?genre=article\&issn=13504630\&volume=18\&issue $=1 \&$ spage $=39$

\title{
Ambivalent Islam: The Identity Construction of Muslims under Portuguese
}

\section{Colonial Rule}

\author{
Mário Machaqueiro* \\ CRIA-Centre for Research in Anthropology, FCSH-New University of Lisbon, Portugal
}

\begin{abstract}
This article wishes to contribute to the study of the historical processes that have been spotting Muslim populations as favourite targets for political analysis and governance. Focusing on the Portuguese archives, civil as well as military, the article tries to uncover the most conspicuous identity representations (mainly negative or ambivalent) that members of Portuguese colonial apparatus built around Muslim communities living in African colonies, particularly in Guinea-Bissau and Mozambique. The paper shows how these culturally and politically constructed images were related to the more general strategies by which Portuguese imagined their own national identity, both as 'European' and as 'coloniser' or 'imperial people'.

The basic assumption of this article is that policies enforced in a context of inter-ethnic and religious competition are better understood when linked to the identity strategies inherent to them. These are conceived as strategic constructions aimed at the preservation, the protection and the imaginary expansion of the subject, who looks for groups to be included in and out-groups to reject, exclude, aggress or eliminate. We think that most of the inter-ethnic relationships and conflicts, as well as the very experience of ethnicity, are born from this identity matrix.
\end{abstract}

Keywords: Identities; Identity strategies; Ethnic Stereotypes; Portuguese Colonialism; Muslims

\footnotetext{
*Email: mmachaqueiro@netcabo.pt
} 


\section{Introduction}

\section{Portuguese Power and its Identity Predicament}

The present article focuses on the way the Portuguese colonial power managed Islam immediately before and during the colonial wars (1961-1974) in Guinea-Bissau and Mozambique, two regions where Muslim communities could be perceived as threatening to that power. The colonial apparatus that I will analyze included not only the central and local administrations, but also the Armed Forces, intelligence services and the political police - a repressive branch of the Portuguese dictatorship that was crucial to the war effort ${ }^{1}-$ as well as the Catholic Church, which was an integral part of the colonial network even though some of its members voiced significant dissent from the repressive methods that were being used against colonized populations.

I will linger on the identity representations (positive, negative, ambivalent) that members of the Portuguese colonial staff built around Muslim communities living in African colonies. The policies those representations inspired are also considered. I will endeavour to relate culturally and politically constructed images to the more general strategies by which the Portuguese imagined their own national identity, both as 'European' and as 'colonizers' or 'imperial' people. The spotlighted period corresponds essentially to the decade-long war that the Portuguese fought in Africa. These were the years when ministers and colonial authorities began paying increasing attention to Islamic leaders, both in Guinea and Mozambique, moving from open hostility to a seductive approach that tried to persuade influential Muslim dignitaries into becoming allies of the Portuguese war strategy against the liberation movements (Garcia, 2000, 2003; Monteiro, 1993). This triggered the emergence of power relations whose main characteristic was ambivalence, with both the Portuguese and Muslims exploiting each other in a system sometimes close to patronage but always tainted by mutual suspicions. 
My basic assumption here is that one cannot properly understand the Portuguese colonial rule without taking into account the position Portugal occupied in the hierarchy of the worldsystem. Since this position was that of a semi-peripheral country trapped in the double condition of 'modernity' and 'backwardness' (Santos, 2002), Portuguese identities could only reflect that intermediate condition, always swaying between megalomaniac self-images of imperial designs, and shameful, depressing or self-debased representations, the former compensating the latter in a symbolic and rhetoric strategy. It is this wavering between a selfdebased image, always at odds with its own frailties, and a messianic identity project, that explains why the elites of Salazar's dictatorship pushed the Portuguese into a war that was being fought, sometimes with unexpected success, when every other European core country had already abandoned the colonial framework. Ambivalence is the key word here, both for the self-image of the Portuguese and their representations of 'otherness'.

\section{Patterns of Muslims' Depiction}

One can detect distinctive patterns in the relations of Portuguese colonialism with Islam and the Muslim populations. From the 1940s, and even earlier (Enes, 1946, pp. 212-215), until the first half of the colonial wars period (1961-65), Muslims were conceived as menacing and unmanageable. A whole array of ideologues, military men, political policemen and colonial anthropologists described how Muslims, inspired by the doctrine of Pan-Islamism, were keen on undermining Portuguese power (Rodrigues, 1948; Dias, 1956; Franklin, 1956). At the same time, the 'animist' populations of Guinea and Mozambique were considered to be potential allies of colonial interests. Unlike Islam, impervious to Portuguese 'Western' values, African 'native' religions were not taken seriously and 'animists' were thought to be pliable to Catholic preaching and Portuguese propaganda. However, the late 1960s witnessed a dramatic shift in this view due to the knowledge that had meanwhile been acquired. Now the 'experts', particularly those who worked in the intelligence services, saw the local Muslim leaders as the preferential allies of colonizers. The assumption was that these leaders had 
become gradually aware of what they stood to lose in future African independent nations ruled by Marxist 'atheist' regimes. The 'animists', on the other hand, were known to have been recruited by the nationalist movements and served as their main supporters, thus becoming lost to the Portuguese cause (Cruz, 1968; Vieira, 1971).

This article intends to focus on the main evidence of the first cluster of images and strategies, a cluster that has never been completely erased from the coloniser's mentality even when a more friendly approach to the Muslim populations was rehearsed. In the concluding section, I will try to overcome a merely descriptive approach in order to understand the kind of identity processes of inclusion, exclusion and compensation that were going on behind the ideological façades.

\section{Islam and Black Africans: a 'natural' liaison}

The Portuguese construction of the 'threatening Muslim' reaches as far back as the nineteenth century, when the Portuguese were forced to legitimize their imperial pretensions in Africa and find their place within the new European colonialist project by effectively occupying their territorial domains in Guinea-Bissau, Angola and Mozambique (Telo, 1994). In 1893 António Enes, a major booster for the military control of Mozambique, wrote a report in which he underlined 'the constantly renewed invasion of the Province by Asians who were as dense and voracious as locusts', considering them a useless 'plague' (Enes, 1946, p. 51) - a very common rhetorical device in negative depictions of the 'Other'. Among those nasty Asians, Muslims stood out. Enes' indictments already contained most of the commonplace accusations spread by racist and Islamophobic discourses regarding the Islamic influence in Africa, which would be endlessly reproduced by so many ideologues and ethnologists. According to this brand of 'social Darwinism', Islam was well attuned to black Africans since they belonged to an 'anthropologically inferior type, usually close to the anthropoid and unworthy of the name of man', as defined by Oliveira Martins (1978, pp. 63-64, 254), a 
famous Portuguese historian and politician contemporary of António Enes. Therefore, 'Mohammedanism' was a religion that perfectly fit the 'natural' shortcomings of Negroes:

A religion devoid of dogmas, mysteries, philosophy, abstraction, mysticism, austerity, a religion for limited intelligences and people close to their natural state, [it] becomes even more simplified and easier in order to be accepted by the Africans - and accept it they do. (Enes, 1946, p. 214)

This idea of the 'naturalization' (or essencialization) of Islam as a religion congenial to Africans was still quite visible in texts produced much later, such as this 1967 report on the influence of Islam in Mozambique written by the local branch of the Portuguese political police:

In sharp contrast with the Catholic religion and, in general, with all Christian religions, Islamic theology has a rather simplistic character ... Islamism does not demand that its believers adhere to a metaphysical concept of life, but just that they organize their existence according to rules which are more pragmatic than moral, rejecting at the same time the Christian principle of the ascendant destiny of Man. (Author?, 1967b)

In the power competition that opposed the Portuguese administration to Islamic influence, the former derived some symbolic profit in underrating Islam whenever it was compared to the highlights of Christianity (that is, to 'Western civilization', 'white power', and so on). The statement by the political police reproduced above could also easily be related to another report produced in 1968 for military purposes, thus painting a single picture of the stereotype regarding the 'natural' link between Islam and the African native:

The Negro, always ready to embrace any ideology, easily accepted Islamism, a doctrine which was in several respects adjusted to his way of life and sometimes corresponded to his natural yearnings. ${ }^{2}$

This connection was made, among many others, by Hélio Felgas, a military officer and ideologue:

... Islamism exerts an undeniable fascination upon the African's spirit, one that comes from the simple way the doctrine is presented and the lassitude of its moral precepts - which, for instance, admit polygamy, still so ingrained in the African mentality. Whereas Catholic missionaries demand from the Christian catechumen a rather complex preparation, Islam merely requires a formal profession of faith. (Felgas, 1965, p. 10) 
Such an identity portrait could be given 'scientific' legitimacy by transferring the 'natural', almost biological, connection between Islam and black Africa to a more 'cultural' one. A colonialist branch of Portuguese anthropology served this purpose. José Júlio Gonçalves, who worked within the Portuguese colonial research institutes, in 1958 published a study that was considered, for many years, to be the single authoritative reference on Islam in Portuguese scholarship (Vakil, 2004, p. 26; Macagno, 2006, p. 90). As we shall see, this book was filled with prejudice and stereotypes, namely the one according to which there existed a natural bond between Islam and blacks. Such ideas were now cast in an ethnological language: 'Certain affinities between the modus vivendi of Muslims in the North of Africa and Arabia and the one of black Africans give a greater penetrating power to Islamism' (Gonçalves, 1958, p. 69). Specifically, in order to explain the great success of the Islamic religion in Africa, Gonçalves resorted to a sexual theme that obsessed these impromptu Islamologists, disclosing their anxieties when faced with the seemingly overt sexuality of black people: Islam tolerated polygamy as a time-honoured African institution, and, according to them, this fact accounted for the 'natural' bond between blacks and the Islamic religion. Such arguments were so pervasive that, as late as 1965, an Army officer reported that:

\footnotetext{
Regarding the Christianization of the peoples of Guinea, it must be pointed out that their scarce permeability to the Christian religion is motivated by reasons of a moral ethnic order, while the Qur'anic religion accepts polygamy. On the other hand, Islamism as embraced by the Fulbes, Mandingo, Biafadas, Nalus and Sosso, and also by parts of other ethnic groups, is characterised by fetishist regressions that are a point of contact with the largest percentage of Guinea's animist peoples. For this and other reasons, it seems that Animists have for a long time tended to embrace the Qur'anic religion, because it would not cause any significant change in the tribal and family structure they are used to. (Correia, 1965)
}

In all this, Portuguese ideologues were following in the footsteps of other colonial traditions, in particular the French school, which contrasted a superficial, 'ignorant' and 'syncretistic' 'Black Islam' with a deeper and truer Asian/Indian/Arab Islam, considered to be the major - if not the only - source of Islamic culture in Africa, while ignoring the African networks that had allowed for the spread of Islam in the Sub-Saharan regions centuries before 
(Harrison, 1998, pp. 94-117; Froelich, 1962; Monteil, 1971; Dias, 2005; Triaud, 2006, pp. 276-277; Bonate, 2007a, pp. 9-12, 2007b, 2008).

Two identity characters may be found within such a perception of 'Black Islam': the 'true Muslim' of non-African origin, the one who concentrated all the paranoid fears of colonial ideologues and administrators, and the 'black Islamized', considered to be a 'superficial' or 'fake' Muslim and, therefore, more manageable by the colonial power because still open to Western Christian influences. I will next examine the role these two figures played in the colonial imagination.

\section{The 'Threatening' Muslim}

\section{'Un-Portuguese' Islam}

In a paper with the significant title of 'The Islamic Threat in Portuguese Guinea', presented in 1956 to the Fourth Congress of the União Nacional, the single legal political party under Salazar's dictatorship, Sousa Franklin summarized the commonplaces of the 'Muslim danger':

Sectarian of a superior religion, endowed with a relative level of culture that singles him out from the animist population, enjoying a higher standard of living, the Muslim preserves himself as he is and rejects any influences from our civilization. (Franklin, 1956: 9)

The scandal associated with the presence of Muslims among us - or in 'our' colonies derived from the perception that they refused to acknowledge the superiority of 'Western civilization'. This was felt as a blow to 'our' identity pride. How could Muslims under the colonial domination of France not want to become French, or the Islamized of Guinea dare to proclaim themselves not Portuguese but Arabs? (Franklin, 1956, p. 17) In the early 1960s, not only the ideologues but even local colonial authorities were aware that Islamism represented, for 'indigenous' Africans, a way of identity promotion that was alternative and much more attractive than Catholicism. See, for instance, a 1961 report from a Portuguese Artillery regiment stationed in Nampula, Mozambique: 
... The Mohammedans consider themselves as superior and emancipated to such an extent that they contemptuously call 'indigenous' those who do not profess their ideals, while they stop considering themselves as such. (Author?, 1961)

This report also stressed, as worthy of criticism, certain visible markers of identity displayed by Muslim native rulers: they preferred the 'Oriental flag' to the national (Portuguese) one, and typically presented themselves in Oriental clothes. Even though the authorities insisted on peaceful methods to seduce the 'Islamized', they were ready to exert repression in the symbolic field where visibility could become an object of power competition. In January 1964, an official bulletin of Milange, Mozambique, reported that ... The Ossemane Chief Assumane Cubualo asked to be authorized to display two flags of the Mohammedan religion in his village where he intends to perform his cult. Permission was denied. (Author?, 1964)

The above-mentioned Júlio Gonçalves had already written of a 'Muslim faith that was undeniably un-nationalizing and ... anti-Portuguese' (1958, p. 169). Lobiano do Rego, a priest and Salazarist ideologue ${ }^{3}$, asserted that

A Muslim has to be religiously and politically Muslim, in such a way that a "Portuguese Muslim" does not make any sense. Therefore in Mozambique the answer in respect to the issue of nationality often is: 'I am a Muslim (not Portuguese). (Rego, n.d., p. 290)

Ideologically concocted, these images influenced the minds of the colonial field agents. See this military report in which the 'un-Portuguese' feature of Islam was candidly linked to a pernicious Arab agency:

The native says that the Mohammedan is not Portuguese! The native who belongs to the Mohammedan religion immediately sees himself as an Arab, under Arab power, and disowns his fatherland with no remorse, rather, with huge satisfaction. He insists and asserts that he is under no circumstance Portuguese; and such conviction has obviously not been reached independently, it is not the fruit of his imagination, but comes from the disintegrative action of Arab agents. (Sousa, 1954)

The 'un-Portuguese' character of Islam was also emphasized by Jorge Dias, an anthropologist whose career speaks volumes on the promiscuous relations between social science, Salazarism and colonial power: ${ }^{4}$ 
The Indian cultural influence is enormous in Mozambique. One merely has to notice their vast mosques, some of which of recent construction and with many modern amenities ... In Lourenço Marques [current Maputo] there are even Indian movies shown without Portuguese translation. In the streets, the posters that advertise the movies are written in Eastern characters. (Dias, 1956, pp. 10-12)

Within the multiethnic Mozambican context, it was possible to give the 'Islamic threat' a more concrete face and put the blame on the Muslim Indians who had settled in that colony, a group pejoratively designated as 'monhés' (Alpers, 1999, p. 167). Another report from the commander of an Infantry Regiment, transmitted in 1959, described their impact on the ‘natives', complaining about

The action, absolutely harmful to the national interest, that results from the presence of the 'monhé' who indoctrinates the indigene, impregnating him with his culture, his religion and his history. ... The monhé fiercely fights Christian marriage, and ... there are many broken marriages due to his actions, taking advantage of the well-known superstitious tendency of the native. (Cruz, 1959)

The unbearable point for the self-pride Portuguese colonialism tried to insure was the fact that Muslim Indians in Mozambique did not respect the boundaries that the colonial power assigned to them:

While several minorities preserve their original religion and try to keep it alive among all the members of the group and their descendents, which is acceptable, Muslim Indians are a serious threat to Portuguese sovereignty thanks to the permanent propaganda (among natives) of the Islamic faith, together with the slogan that that is the religion of the colored men, while Christianity is the religion of the white men. (Dias, 1956, p. 1).

Jorge Dias was also worried that Muslim Indians brought to light a connection between religion and ethnicity (or 'race'). Christianity, a culture that pretended to be ecumenical and universal, was thus denounced as particular and relative, attributes that the colonial ideologist would surely have liked to reserve to Islam and other 'inferior' faiths:

... The biggest danger comes not from the fact that Indians are an ethnic minority, but from the fact that they try to oppose the efforts of the Portuguese to assimilate the indigene, [and they do so] by spreading a religion that is going through a phase of great expansion in Africa, which they call the religion of coloured men. The barrier they attempt to establish between the two religions, associating each one with a 
pseudo-racial group - white and coloured (black) -, is highly dangerous and may have severe consequences if it keeps advancing. (Dias, 1956, p. 8)

As Susana Bastos recently showed (2008), this phantasmatic view of Muslim Indians in Mozambique as a 'counter-power' that could undermine Portuguese domination did not have any correspondence in a real mobilization on the part of the targeted Indians, who either kept an apolitical demeanour or, in some instances, became involved in active collaborationism with the agents of colonial power, namely the political police.

\section{The geo-politicization of Islam}

On the eve of the colonial wars, such a rejection of any Western identity models was being increasingly equated with straightforward rebellion:

... The Mohammedan rulers have had several meetings in their temples that they claim to be of religious character, but that the white population suspects of also having a political character, opposed to the national sovereignty. (Author?, 1961)

The 'Western' imperial project had met an external enemy apparently capable of challenging its domination. The formation of an Empire, a perfectly 'legitimate' program if carried out by the 'right people', had to be devalued if taken over by the 'wrong people', that is, everyone on the non-Western divide. Without apparently noticing that each of the terms he used could be equally applied to the Catholic project of 'evangelizing', Jorge Dias wrote:

No doubt that the current expansion of Islamism is not simply the diffusion of a religious faith - if ever it was simply that - but one of the processes of political domination by the Islamic world: it is the struggle for Mohammedan hegemony (Dias, 1956, p. 1).

This politicization of Islam implied another strategy of devaluation: Islam was not only too simple a religion; it was not even a religion in the proper sense of the word:

This religion no longer deserves the name of religion, despite being labelled as such, because its action is essentially political, and does not aim to cure the spirit but rather to chain the spirit to a people and not to a god, to a nation and not to a sect. (Sousa, 1954) 
As we had already noted in a number of samples of the discourse about the 'Arab threat', the representation of Islam as a political force in the Portuguese colonial vision was dominated by three interconnected themes, which corresponded to three phantasmatic anxieties: Pan-Islamism, Pan-Africanism and the relation between Islam and Communism. The first one had already haunted some speeches in the National Assembly, the Portuguese parliament controlled by Salazar's dictatorship, ten years before the outbreak of the colonial wars in Africa. These outlined all the commonplaces of the Pan-Islamist 'threat':

Intensified over the last centuries and with a larger size and significance than it is generally supposed by

Europeans, who are much too optimistic, the Pan-Islamist movement has the capital aim of suppressing

Christianity in Africa and, no less seriously, opposing in the name of faith what we call Christian and Western civilization. (Moreira, 1951)

When the colonial wars in Mozambique and Guinea-Bissau were in their most active phase, some secret reports issued by the political police imbued Islam with the ability of a mediator capable of making the synthesis between different African traditional creeds, thus reinforcing their 'otherness' in contrast to Western 'values' and turning them into a powerful weapon against European colonial domination:

... Islamism has the ideal conditions to produce the symbiosis of tribalism and fetishism, attributing a sacred dimension to all the atavistic features of the local indigenous masses, which raises the possibility that they will be captured by the ideas preached by the enemy. (Author?, 1967b)

The above-quoted Hélio Felgas expressed his concerns that Africa, traditionally 'so heterogeneous, so tribal, so hostile towards itself', could be heading towards a 'large campaign for unification', and that 'Islamism' could be used as a tool for achieving it, despite counting on the hatred that usually divided Arab countries (Felgas, 1965, pp. 19-20). These concerns beset the daily affairs of the Portuguese colonial administration, which assigned a number of Intelligence and political police officers to the specific task of collecting all available information on the trends of the Islamic and Arab world.

The most extremely paranoid imageries foresaw a geopolitical landscape where the 'Eastern Islamic Evil' would challenge and threaten the 'Western Christian Good', a cleavage 
that seems structurally linked to a certain idea of 'political Islam'. Some voices inside the Catholic Church viewed Pan-Islamism as an intrinsic and irremovable quality of the Islamic religion:

Times have changed. But what has not changed is the Muslim fanatic mystique which, sustained and prompted by Arab nationalism, dreams of restoring the old Ottoman empire, also encompassing Africa (Cardinal Gouveia, as cited in Rego, 1959, p. 79).

Sousa Franklin did not stop short of predicting a 'Holy War' of the Crescent against the Cross that would mobilize 'the entire Islamic world' and launch a global terrorist network led by 'volunteers of death' (1956, pp. 15-16, 18). This imagery serves to aptly illustrate how far back we may trace the source of our current nightmares about a 'terrorist Islam'.

There were, however, some Portuguese colonial agents who tried to develop a more balanced picture of Islam, one that could measure its 'dangers' with greater accuracy. Following a definition subscribed by other European Islamologists, especially those belonging to the French school, they identified Islam not with the traits of rigidity that are nowadays so commonly ascribed to Islamic culture, but with the signs of fluidity - as if Islam was a kind of plasticine religion ready to adapt itself to any cultural mould (Bonate, 2008):

... Islamism integrates an extraordinary plasticity, unheard of in other great religions, [a plasticity that] moulds itself perfectly to the ethnic conditions of African peoples, thus allowing for an almost perfect coexistence. (Author?, 1966)

This plasticity was double-edged and therefore ambivalent: it meant that Islam could be easily adjusted to fit the subversive anti-colonial movements, but on the other hand it opened a space for manipulations in favour of the Portuguese interests (Author?, 1967a).

On the other hand, concern regarding the possible alliance between Islam and Communism in Africa was pervasive in the analyses produced, in the early 1960s, by the Portuguese authorities, especially amongst the Armed Forces and the political police. In this particular case, one could see all the ambivalence regarding Islam, which was presented either as a dam, although frail, against Communism in Africa, or as an agent of Communist penetration. But the explanations for such an alliance also stumbled on the characterization of Islam: either 
they saw it as a kind of twin-brother of Communism, and even as Communism avant la lettre, or they thought Islam was being perverted by Communist ideologues who were essentially alien to its true meaning.

While recognizing some important differences between the two, Felgas stressed a deeper likeness in the fact that both Islam and Communism shared hatred towards the West and a wish to conquer the world by overcoming all national borders (Felgas, 1965, pp. 15-17). A political police report, wavering between sophisticated analysis and delirious nonsense, went even further and pictured Mohammed as a predecessor of Karl Marx:

... He preached the "holy war", which he carried out, fought against capitalism, stood by the poor and the oppressed, raised the problem of the "class struggle" and directed Islam towards the ethical, scientific and political fields. (Author?, 1966)

Voicing all the 'Western' dismay before the perspective of an 'Afro-Asian cooperation' in the struggle against imperialism and capitalism, this text interweaved Pan-Islamism, Marxist socialism and anti-colonialism:

... With Islamism fighting capitalist exploitation, a clear opposition has been created between the Islamic world and Western capitalism, producing the theory known as "anti-colonialist struggle".

Thus one can see that, in practice, Marxist socialism and Islamism only differ in their application of revolutionary methods, while they are close in the essence of their struggle to join efforts against imperialism and capitalism. ${ }^{5}$

Portuguese power, isolated as it was in the international scene, was painted by Salazar's regime as the last barrier against those interrelated perils. There was, however, the ongoing suspicion that such an image was out of proportion to the truth.

The 'Superficial' Islamized and the Identity Rivalry between Portuguese Catholicism and Islam

\section{A 'Fake' Islam}

Engaged in a power rivalry, the Portuguese authorities and ideologues recognized the strength of the Islamic influence and the prospect of its superiority, which threatened to disrupt the 
Catholic (Portuguese) ascendancy over the African populations - an ascendancy which, due to lack of means, was always more rhetoric than actual fact. Around 1948 Sarmento Rodrigues, a High Commander of the Portuguese Navy who held various important posts in the colonial administration - including the one of Minister of the Colonies -, while governor of Guinea, expressed the identity distress brought by a comparison between the 'weakness' of the Portuguese in that colony and the 'power' of their Islamic rival:

We see the Biafadas, who were Fetishists, becoming Mohammedans and adopting Mandingo names, their religion and habits, something I find shameful to us, because it reveals that the influence of the Islamized is greater than ours. (as cited in Franklin, 1956, p. 8)

The narcissistic dreams of Portuguese colonialism were doomed to be confronted by the structural paucities of Portuguese society. Thus a feeling of identity 'shame' that always haunted the attempts of the central powers in Portugal to come closer to, or even to surpass, the 'Western' model of colonial domination. These attempts included a very well-known strategy in which the inculcation of the colonist's religion into the colonized 'other' was seen as a necessary condition for the latter to be assimilated (Cross, 1987, p. 556). Such assimilation aimed to replace the identity of the 'bad' native with that of the 'good' colonizer. This idea ran through Portuguese colonial ideology, especially throughout the regime of Salazar. A highly influential figure in the construction of that ideology, Sarmento Rodrigues wrote that the 'Christianization of the Gentiles' meant both 'civilization' and 'nationalization' (Rodrigues, 1948, p. 225), a model that could be simply achieved by turning African natives into Portuguese nationals. Of course, this kind of reassuring suppression of 'otherness' did not, by itself, put an end to hierarchies that were so important in identity assessments. In fact, while picturing the 'good will' of Portuguese colonialism, Rodrigues resorted to a familybased image of 'brotherhood' that did not cancel the difference between 'older' and 'younger' brothers, often displayed when identity hierarchies are at stake:

For our intention, ever since we first set foot on these new territories, has always been to raise the primitive peoples and to make them like us, our brothers in everything, and to offer them a fatherland, our fatherland. (Rodrigues, 1948, p. 225) 
Sousa Franklin attributed this desire for an identity transfiguration to the natives themselves, who were supposedly eager to become 'Portuguese' and 'white', even though, in their original 'inferiority', they were reduced to a kind of identity mimicry. Unable to be 'real' Portuguese (or 'real' white men), the African natives could only imitate their external traits:

Every native attracted to Christianity is, one may say, a Portuguese. To the primitive mindset, being Portuguese equals being Christian. Being Christian offers a chance to come into contact with the white man, to attend side by side the same religious ceremonies, which for the native means ascending to a higher social level. ... It is but a small step from becoming a Christian to becoming a Portuguese, since the native immediately wishes to learn to speak Portuguese, to dress in the European style, and to act civilized, in short, 'to be as a white person', while distancing himself from his peers. (Franklin, 1956, p.

This construction deserves some further analysis. On the one hand, it acknowledges the role of visibility in identity strategies: black Africans were supposed to promote their identities through a certain display of visible signs. On the other, it reduces the range of such a promotion to that very visibility, suggesting that Africans would never be able to bring their position on a level with Europeans. According to this view, the 'transformation into a Portuguese' (or 'Westernization') of Africans would always be an external artifice instead of corresponding to an inner change. This helps to explain why the hierarchical abyss between 'native' and 'civilized' persisted in Portuguese colonial practices, even after its formal abolition in $1961 .^{6}$ It also allows us to understand the ambivalence that affected the status of the 'assimilated' African, who lived in a no-man's land between a black identity and a white European one, the possession of which he was always forced to prove to the colonial authorities (Melo, Capela, Moita, \& Pereira, 1978, pp. 60-61; Macagno, 2006, pp. 56-57).

Having thus asserted the insurmountable limits of identity transformation for black people, the question was to know whether that external change would adhere to a 'white Christian' referent or to a 'non-white Islamic' one. For Portuguese ideologues, the type of 'Muslim' behaviour Africans were capable of was as superficial as its 'European' counterpart. In both 
cases, Africans were thought of as having their identities exclusively devoted to an exterior form, a kind of superficial façade. We can find an instance of this perspective in Júlio Gonçalves. According to him, the populations of Guinea drawn to Islamism were as far from a true Muslim identity as those blacks, depicted by Sousa Franklin, who clumsily tried to look 'European'. They were not exactly Muslims, but 'Islamized'. No matter which 'superior' model they embraced, blacks were unable to reach its 'essence', using it only for purposes of identity upgrading:

The Islamized blacks, possessed by a true megalomania, flaunt with pleasure the symbols of their superiority in respect to their blood kindred: the kaftan and the turban which, by the way, are more accessible to their weak economic power than any European-style garment' (Gonçalves, 1958, p. 73). ${ }^{7}$

One may better understand the psychological effect of these garments if one has already seen an African native 'dressed' in the tribal fashion, side by side an imposing Islamized in all his false majesty; a toasted black face, contrasting with ivory-white teeth, a spotless white djellaba and an equally light-coloured turban! It is no surprise that a poor African Negro should wish to uproot himself, send his children to the mosque and to school and become a follower of a religion that, even though it brings some harm, will elevate him in the eyes of his fellows ...! (Gonçalves, 1961, p. 26)

The accusation thrown at Islamized Africans was that theirs was a false Islam, entirely focused on a performance whose artificiality collided against the 'deep primitive nature' of the Negro:

These Negroes, drawn to the prestige of the kaftan, are pathetic. They sometimes live as if obsessed with its importance, as if nothing else mattered. One has only to see them coming in haste to the villages through the neighbouring jungle; as they approach, their entire natural demeanour vanishes, their exuberance dies and they dress with care. Then they enter solemnly, standing very straight, falsely upright! In a way, they remind one of the naïve European peasant when he comes to town. (Gonçalves, 1961, p. 26)

Note the analogy between 'peasants' and 'colonized peoples', so frequent in this kind of identity construction, something that would deserve, by itself, a whole study. A common trait emerges in all these assessments of the behaviour of Muslim natives: it was not seen as a serious or genuine manifestation. In this case, the power strategy of the colonial discourse was not exactly to deny African Muslims their visibility. It was to simply conceive it as a surface 
without any 'real' content. Behind the 'façade' lurked the same old 'childish' Negroes portrayed in the founding texts of colonialist racism.

Once again, we detect here the prejudices inherent to the idea of 'Black Islam': the 'Islamization' of Africans was nothing but a shallow process, unable to disguise an everpresent 'animist' setting:

Those who believe that the Islamized Negroes of Guinea are genuinely so would be gravely mistaken.

Their Islamism is superficial and often apparent; their old animism remains unchanged in the background, as shown by their many amulets. (Mota, 1954, p. 251)

All in all, the identification between nationality and religion was a double-edged sword: while it allowed the 'native' to picture himself as Portuguese just because he became a Christian, it could also alienate him from Portugal whenever he felt himself to be Muslim. As a matter of fact, the project of 'nationalizing' the 'natives', which was tantamount to the erasure of their identity, was being challenged by an Islamic presence recognizably stronger than the Portuguese Catholic one. Sousa Franklin feared that 'Fulbes, Mandingo, and other Islamized peoples that today behave like good friends will tomorrow raise the banner of rebellion and turn their weapons against us'. And this because they lived 'isolated as if on islands', 'rejecting any alien influence' and with a 'political and social structure strongly committed to religious principles'. In such conditions, Franklin thought 'they will not hesitate to betray those who always gave them friendship, understanding and freedom' (Franklin 1956, pp. 24-25). In 1959, a number of military reports showed concern that the 'Islamized tribes, who in the past helped us to pacify Guinea[-Bissau], are precisely those that may bring us trouble, given their affinities with the already emancipated tribes of the Republic of Guinea and the Senegalese tribes that are going to present their claims for freedom and emancipation' (Rodrigues, 1959). 


\section{Strategies to hamper Islamization and attract the 'Animist'/'Islamized'}

The Portuguese administration asked itself how it could avert all this. In a context of power competition, the Portuguese tried to contend with Muslims - the 'true' ones - for influence over the 'Animists'/'Islamized'. The identity representation of a superficially Islamized African, bearing all the marks of anthropological 'inferiority', made the colonizers believe that he could still be reclaimed by the Portuguese. This hope transpired from a study on the missionary movement, classified as 'secret' and sent both to the research centre that sponsored it and to the dictator Salazar:

The safer way to convert Muslim Negroes to Christianity is to draw them out, step by step, of their environment ... It is falsely believed that any attempt in this sense is useless, but this has not yet been proved. One has to agree it is more difficult. But difficult does not mean impossible. The Islamized have few strong notions. Their faith in the Qur'an is not blind, being bound to the jungle as they still are... Christianity was able to penetrate not only in regions that were not very Islamized, but even in those that seemed immune to the Catholic faith. (Rego, Silva, \& Gonçalves, 1960, p. 121)

Thus the programme laid out by Monsignor Martinho da Silva Carvalhosa, Apostolic Prefect of Guinea, in a letter addressed to the Minister for the Colonies: 'The natural order of things dictated a plan to be followed: to expend the greatest possible effort to preserve the Animists from the influence of the Moorish...' (Carvalhosa, 1958). The colonizers could adopt the usual prescriptions to hinder the expansion of Islam - procedures like the spreading of Catholic missions or the compulsory use of the Portuguese language in Islamic schools (Bonate, 2008). Several official documents, either from the central powers in Lisbon or from local authorities in the colonies, including the intelligence services, insisted on the mandatory learning of Portuguese as a strategy to bring the colonized populations under the guidance of Portugal and to avoid their being attracted to anti-colonial propaganda, which was supposedly connected with Islamic indoctrination. ${ }^{8}$ Sometimes the struggle against the Arabic language could be put in forceful terms such as those employed in a paper about the influence of Islam in Guinea-Bissau, presented to the $1^{\text {st }}$ Congress of the Portuguese Communities in December 
It is not enough to oppose the teaching of the Arab language! It is necessary to forbid it! Indeed, to forbid it as a lingua franca of Guinea, to sweep it from the schools where, side by side with the official language, it has the advantage of the religion it disseminates. To forbid it, yes!' (Lima, 1964, p. 5)

Lobiano do Rego was even more radical in respect to the Muslim presence in Mozambique, arguing for a complete banishment of activities that were specifically Islamic, of 'any kind of proselytism', something which implied, of course, the interdiction of Islamic schools. Ironically enough, he said that this 'vital Portuguese-Christian reaction' erupted out of love, 'big, generous Love, in proportion to the universal Good' (Rego, 1959, pp. 81-82).

These were isolated voices, even though they bluntly expressed the thought of many within the administration. But the Portuguese colonial authorities, well aware of their own structural inefficiencies, knew that force was not a suitable solution to deal with the 'Muslim problem'. Thus their option for a cautionary strategy that always went on a par with the rhetoric of 'Empire'. In the official discourse, both in public speeches and classified documents, we find many instances of a circumspect approach to the Muslim populations. After all, it was wise not to openly confront them:

Only those who have borne the responsibility of managing the colony [of Guinea-Bissau] may have felt the consequences of the implementation of certain measures that can hurt the natives' religious feelings, especially when they are Islamized people. (Viegas, 1946, p. 661)

This situation seems to urge the greatest caution in what concerns the religious policy to be enforced in Guinea, because the Islamized population has a higher cultural level and better fighting abilities. It thus becomes essential to try to attract the Islamized population while avoiding to exert any religious pressure upon them, a pressure that, until now, has been ineffective in respect to the goal of converting them to Christianity. (Author?, 1960)

Helena Lima conceived another device to attract the black animists or the superficially Islamized to the Portuguese side. That device reflected all the abovementioned ideas about the true motivations that pushed the Africans to Islam. If the garments, the djellaba or kaftan, were the real driving forces behind the conversions to Islam, then the Portuguese should propose an alternative dress even more attractive and supportive of identity pride. Conceiving this as policy to be implemented by local authorities, Lima suggested a kind of sleeveless 
overalls, combining the worker's dress with a military touch that would surpass the fascination that the white djellaba was believed to exert on the recently Islamized Africans of Guinea-Bissau. In a discourse full of erotic phantasms that betrayed the repressed sexuality of a European Catholic woman, Lima anticipated the effect of such a garment (Image):

When he walks, the Muslim does so in large strides; and when he sits, he opens his legs, and takes up a large space with his garment. He is imposing but not virile. The native in a loincloth is neither the former, nor the latter. The overalls on their handsome black bodies, some of them with an enviable build ..., would make them even more masculine and westernized... (Lima, 1964, p. 6)

\section{Image}

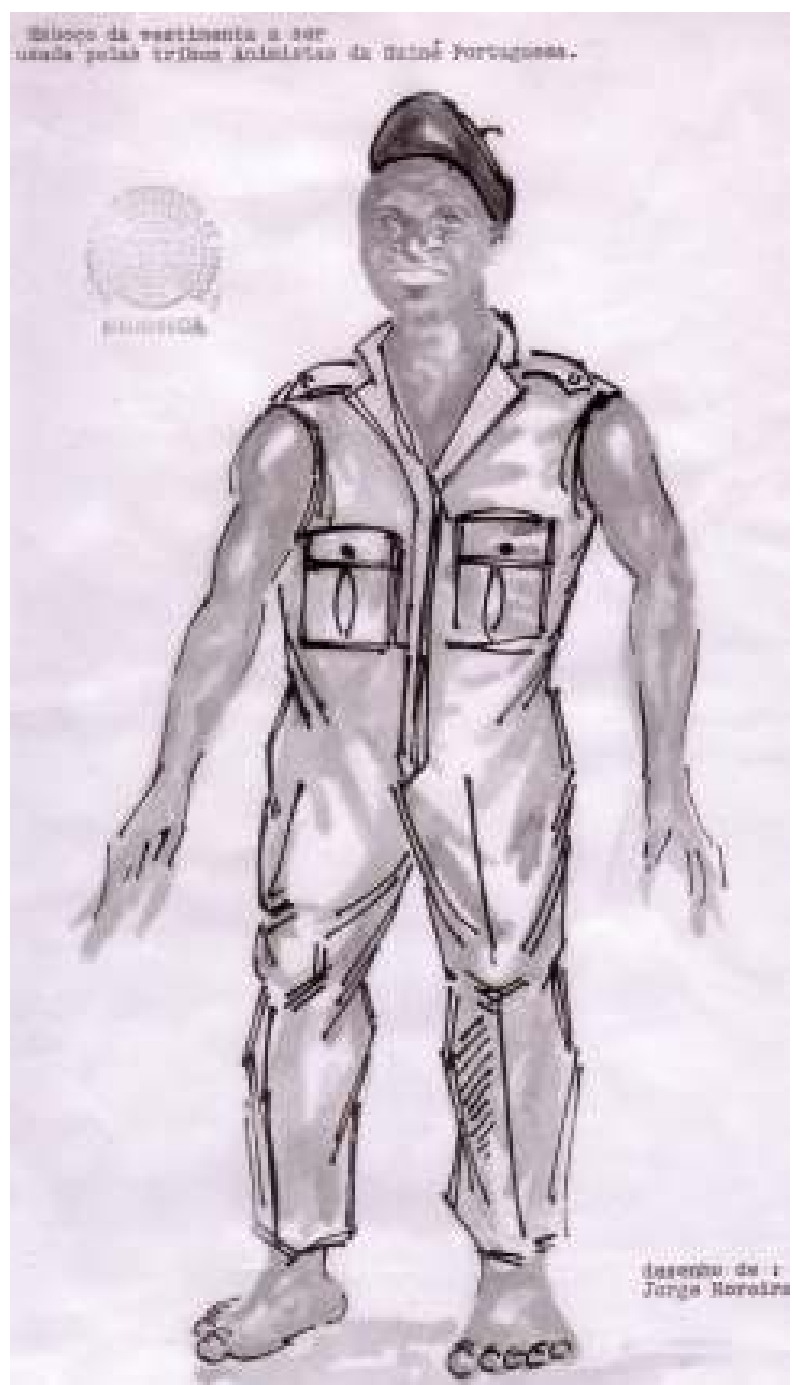

Translation of caption: 'Sketch of the dress to be used by the animist tribes of Portuguese Guinea' 
And she concluded that 'only with manly clothing and manly appearance he would be able to overcome the influence of Muslim attire', for 'dressing the native of Guinea means creating a Portuguese man' (Lima, 1964, p. 7). This means that to be 'Western' and 'Portuguese' was to become 'manly', whereas to be 'Muslim' was to become 'feminine'. On the other hand, the native that wore a loincloth - exhibiting his own culture - was neither masculine nor feminine. He was sexually indetermined, another way of saying he was a child - a characterization typical of all racist depictions of African people. Therefore, two paths were opened to this Animist 'child': either he became 'masculine' ('Western' and 'Portuguese') or he would become 'feminine' ('Muslim').

Grotesque as this discourse may seem, it not only reveals how far the colonizers were ready to go in order to control the colonized bodies, but also shows that they still nourished the hope of attracting the animist populations to the Portuguese side, in spite of an expanding Islam.

However, as the colonial wars were evolving on increasingly demanding terrains (Cann, 2005), a new strategy was devised that implied a whole new image of 'Black' or 'African' Islam - or, at least, the varnishing of older pictures. By the end of the 1960s, the official policies towards these communities suffered a profound change. The political climate regarding the African Islamized was overhauled, and those who used to be represented as enemies were now singled out as possible allies. A sociological and anthropological explanation was sought for the reason why the Islamized were, after all, closer to the Portuguese power than animist ethnic groups such as the Balanta of Guinea. The latter supposedly presented an 'atomized social structure, and can easily fall prey to the subversive action' of the anti-colonial movements (Cruz, 1968, p. 137). On the other hand, and according to Luís Correia da Cruz, the social organization of the Fulbes, the largest Islamized ethnic group of Guinea, was much more unified, structured around religious leaders that would not accept the replacement of their traditional order by the socialist make-up that the anti-colonial movements could eventually impose (Cruz, 1968, pp. 137-138; Vieira, 1971, pp. 609-610). 
There were even some high-ranking figures within the Portuguese administration who seemed ready to hand over all powers to the Islamized Fulbes in case of a complete collapse of the colonial system. In a meeting that took place in the Ministry for the Colonies, Deslandes, a representative of the Portuguese Ministry for Foreign Affairs, went as far as to advise that 'the greatest administrative de-centralization should place all powers in the hands of the Fulbe group':

It would then be advisable to arm the Fulbes, to whom sovereignty should be given if the time comes for our military forces to leave the territory, beaten by the forces of subversion. (As cited in Monteiro, 1964) ${ }^{9}$

Such an eccentric suggestion was immediately dismissed, but it nevertheless showed the kind of feelings that some politicians nurtured towards the colonized Muslim. Those feelings reflected a whole new scenery for the relationship with Islam. The next step would be to seduce the Islamic leadership into forging an alliance with Portuguese interests against the liberation movements in Mozambique and Guinea-Bissau. This was attempted, however, when it was already too late for the Portuguese colonial delusions to have any feasible future.

\section{Conclusion: The Structure of Identity Constructions ${ }^{10}$}

As we may notice in Figures I and II, the imagination of Portuguese colonialism was crossed by a structural uneasiness about the place that 'Portugal' - an imaginary site - occupied in the symbolic hierarchies of the world-system. From the Nineteenth century until the late 1960s, the identity constructions inherent to the ideology of Portuguese colonialism were far from being linear or univocal. On the contrary, they operated at a crossroads where different and contradictory representations were mixed in tensional dynamic relations between four referents: denied, negative, positive, and ideal identity. In a way, the 'national' identity is nothing but the articulation of these prototypes. The denied and negative identities, put together, delineate the latent identity, the unspoken one, targeted to be repressed, overcome or forgotten. This identity therefore embodies a past that will never disappear, the ever-present background of a whole self-image. The current or manifest identity, more or less coincidental 
with the positive representation, has a silenced and uncomfortable relation with the latent one. At the two farthest poles we may find the denied identity (unconscious, shameful, nonassumed) and an idealized referent on which the subject invests his project of selftranscendence. The ideal identity derives from the positive one, but it incorporates a utopian or future-driven dimension that the positive identity does not present by itself, being confined as it is to the possible and the current. Superficially, it seems that the conflict between positive and negative identities determines the dynamics of several identity strategies, whereas, in fact, it is the denied one that puts into motion the process through which the others are elaborated. This process, in its completeness - invention and projection of an ideal -, aims at reacting to a deep distress both individual and social, summed up in a self-image that one wishes to delude or overcome. Here, the denied identity was the 'hybrid Portuguese', in whose veins ran the blood of 'Negroid' Arab invaders. Over and over, Portuguese bio-anthropologists, who worked within the frame of Salazar's dictatorship, felt the need to confront all the Western scientists and ideologues, mainly those of Nazi Germany, who persisted in ascribing a black genesis to the Portuguese 'race'. On the verge of becoming the chief of the Colonial Institute for Higher Education and the Board for Colonial Research, Mendes Correia could not do much more than to resort to some dubious anthropometrical 'evidence', all of which, according to him, pointed to a single conclusion: the Portuguese do not have anything to do with Negroes, but belong, by their own right, to the European block (Correia, 1940, pp. 211214). This arguments tried to disavow what had always been 'obvious' to foreign racism: the 'hybridity' of the Portuguese, a sign of an unredeemable 'inferiority'.

The Portuguese allegedly suffered from a bio-ethnic ‘impurity’ or, as Jorge Dias said, from a 'racial lack of determination' so difficult to cope with (1956, p. 9). Colonial ideology tried to redress the resulting shame by suggesting that the other side of that negative threatening pole was simply the ludicrous 'Islamized Negro', the one Portuguese colonists wanted to differentiate from in order to assert their pride. And if the first pole would eventually require a system of control and repression, the second one was much more manageable. After all, his 
Islamism was not serious, it was the weakest link of Islam in Africa and it should not be impossible to lead the Islamized back to the good Catholic side, that is, to subject him to an assimilation process that would confirm the essential 'superiority' of the Portuguese.

In the early $1960 \mathrm{~s}$, as an answer to the growing movements against colonial power, the Portuguese authorities resorted to the idea of 'Lusotropicalism', a concept invented by the Brazilian sociologist Gilberto Freyre $(1983)^{11}$. Celebrating miscegenation with other races, which the Portuguese people supposedly promoted wherever they were, 'Lusotropicalism' allowed the Portuguese colonial domination to be presented not, in fact, as colonialism but simply as a 'special' kind of ethnic relation based on a 'natural openness' towards other cultures and peoples. However, the apparent triumph of 'Lusotropicalism' in the official discourse of Portuguese authorities did not erase the identity construction summarized in Figure I. [Figure I near here] It was basically a large denial operation, whose aim was to gloss over the uncertainty of Portugal's identity position. Far from being a comfortable and problem-free position for the Portuguese people, miscegenation and mestizage were disturbing experiences, even when the authorities encouraged them as a strategy to control territories too vast to be simply colonized. In 1958, Jorge Dias still complained about the fact that in Mozambique many children of mixed couples were being classified under the category of 'natives', which meant that, whenever their white fathers did not recognize them, they were grouped with blacks according to the hierarchical ethnic labels created for racial discrimination. Besides that, Dias saw how the rest of 'white society' tended to marginalize mixed couples (1958, pp. 75-76).

These observations give some perspective to the identity construction that was behind the power relations between Muslim communities and Portuguese colonizers (Figure II). [Figure II near here] The denied identity I spoke about was still implicit. But now the negative pole was dual, composed of two referents, one debased and the other threatening, whose connection was ambiguous and a source of discomfort to the colonial administration. The image of the 'Christian Portuguese' was determined by the confrontation with that negative 
duality, without any chance of foreseeing the outcome of such a struggle. On the other hand, the image of 'Muslim people' was divided into a reassuring 'inferior' side and a 'powerful' one whose strength was, at the same time, abhorred and envied (thus its ambivalence). It is important, however, to remark that the former of these two poles was not completely onedimensional. The ridiculed figure of the 'Islamized Negro', because it was apparently more usable, would soon give place to the idea of a 'Black' or 'African' Islam, something that the colonial authorities were supposed to promote and use as a weapon against the power of 'Arab' or 'Asian' Islam, and especially against the rising anti-colonial movements.

All in all, the Portuguese identity project was still marked by a desire to belong to a "pure white' Western European block, this time defined through a strategic handling of religion the most problematic one, because in that field the Portuguese administration displayed all its weaknesses when faced with the local influence of Islam. That is why the search for a 'friendly' Islam throughout the colonial wars in Mozambique and Guinea did not break in any way with the framework described in Figure II. In the colonizer's mind, the Muslim chosen to be manipulated was far from being a positive role-model. Therefore, the new policy of relations, although based on a much more accurate knowledge of the Islamic religion and culture, was not innovative to the point of establishing a real new paradigm for identity construction.

\section{Notes}

\footnotetext{
${ }^{1}$ The so-called New State, an authoritarian order very close to the fascist regimes in Italy, Germany and Spain, had its political police established in 1933 with the name of Polícia de Vigilância e Defesa do Estado [Police for the Surveillance and Defense of State]. In 1945 a decree changed its name to Polícia Internacional de Defesa do Estado (PIDE) [International Police for the Defense of the State], enlarging its powers and scope of action. In 1969 Marcelo Caetano, the successor of the dictator Salazar, extinguished the PIDE, replacing it by the Direç̧ão-Geral de Segurança (DGS) [General-Direction of Security], which in fact assumed the former's functions in what concerned the control, surveillance and repression of any activities that opposed the dictatorship. Although the political police had been installed in the colonies by 1954, it was mainly from 1961,
} 
when the anticolonial movements burst into scene, that the range of its actions was deeply felt. In Portugal its repressive methods, systematically resorting to brutal torture during the interrogation of political prisoners, were aimed at specific targets, being nevertheless able to spread terror among the whole population, whereas in the colonies the repression took the proportions of an overt mass terror. In the context of the colonial war, the PIDE was instrumental for the military manoeuvres as a branch of the intelligence structure. On the general history of this political police, see Pimentel (2007); on its role in the colonial wars from 1961 to 1974, see Mateus (2004). Besides the thorough study conducted by Dalila Mateus, one can also see Souto (2007, pp. 179-183) on the intelligence services that the PIDE provided to the Armed Forces.

${ }^{2}$ This passage is taken from a very important military report on the religious scene in Mozambique (Author?, 1968). It can be found at least in two different archives in Lisbon: ANTT / SCCIM no. 105, 'Miscelânia sobre cultos religiosos' ['Miscellany on Religious Cults'], 1968, sheets 176-205, and Box ADN/FO/002/02/007/003/03, October 1967-October 1973. In the texts that I am quoting the word 'Islamism' does not refer to a fundamentalist branch of Islam. It simply stands as a synonymous expression for Islam taken as a whole.

${ }^{3}$ Lobiano do Rego was the pseudonym of Albino da Silva Pereira, a member of the Portuguese Catholic clergy responsible for a movement known as Apostle Laymen of National Integration. He wrote several books in which he decried Islam (Rego, 1959, pp. 77-83, 1966, pp. 45-49, 97-122). On the movement of the Apostle Laymen, a kind of missionary 'army' conceived to forcefully promote the Christianization of the 'gentiles', see the documents in ANTT/AOS/CO/UL-32, sheets 1-7.

${ }^{4}$ Considered to be the main figure in Portuguese anthropology throughout the 1960s, Jorge Dias merged the role of a social anthropologist with those of informer and 'spy'. While he was conducting his research on the Makonde in the north of Mozambique at the end of the 1950s, which resulted in the writing of anthropological works praised by the scientific community, he kept sending classified reports to the authorities of the mainland informing on the 'subversive' movements of local populations and ethnic minorities. He actually did that as several other anthropologists who worked within the Centre of Political and Social Studies, a branch of the Portuguese colonial 'research'. In the report that I am quoting, Dias flatters himself of having pretended to be a 'Qur'an enthusiast' just to pick up information about El Azhar University among its students (1956, p. 2). A good example of the secret texts produced by Dias' team, parallel to the scientific ones they were working on, is a 1960 report he addressed directly to Salazar (see ANTT/AOS/CO/UL-37, 2). The interconnection between his anthropological activity and his intelligence work did not raise any deontological problems to Jorge Dias, who was perfectly at ease in the cultural environment of the dictatorship. On this, see West 2006. On the serious inadequacies of Dias' anthropology, also see Macagno (2002). 
${ }^{5}$ For a much more nuanced and well-informed reading of the relations between Islam and socialism, made by a Salazarist ideologist, see Martinez (1970).

${ }^{6}$ Implementing ideas conceived by the Nineteenth-century ideologues of Portuguese colonialism, Salazar's political regime, known as Estado Novo [New State], had promulgated in 1926 the Political, Civil and Criminal Status of the Native, which was to be applied in the colonies of Guinea, Angola and Mozambique. This legal framework denied the African 'natives' all the legal rights of citizenship reserved for 'civilized' people. It was formally abolished in September 1961, but its symbolic and material effects persisted until the end of the colonial war (Cross, 1987, pp. 558-559; Macagno, 2006, pp. 40-55).

${ }^{7}$ Several Portuguese ideologues of colonialism voiced the idea that the Africans who adhered to Islam were mainly attracted to a supposed identity 'prestige' associated with the kaftan, an idea that we can already find in Enes' nineteenth-century report on Mozambique (Enes, 1946, p. 213).

${ }^{8}$ See, for instance, the instruction given by the Governor of the district of Mozambique, in April 1963, advising that teaching in 'Mohammedan schools', even of catechism, should be exclusively carried out in the Portuguese language (ANTT/SCCIM, no. 408, sheet 330). See also the note from the Education services, written in June 1964, which features the same demand (ANNT/SCCIM/H/9, no. 408, sheet 212).

${ }^{9}$ The figure that is mentioned is most probably the General Venâncio Augusto Deslandes, who had been Governor and Commander-in-Chief of Angola in 1961 and served as Secretary-Assistant of the National Defense in 1965.

10 The following analysis will be very loosely based on the theoretical frameworks that two Portuguese anthropologists, José Gabriel Pereira Bastos and Susana Bastos, have been developing in their studies of the Portuguese national identity and the identity representations or strategies of colonized populations, immigrants and ethnic minorities (Bastos, 1995, 2002, 2003; Bastos \& Bastos, 2005; Bastos, 2008).

${ }^{11}$ On the reception of 'Lusotropicalism' in Portugal and the way it influenced the Portuguese ideology of colonialism, see Castelo (1998). 


\section{References}

\section{Acronyms:}

ADN - Arquivo da Defesa Nacional [Archive of National Defense]

ANTT - Arquivo Nacional da Torre do Tombo [National Archive of the Tombo Tower]

AHM - Arquivo Histórico Militar [Military Historical Archive]

AHU - Arquivo Histórico Ultramarino [Overseas’ Historical Archive]

AOS - Arquivos de Oliveira Salazar [Archives of Oliveira Salazar]

PIDE-DGS - Polícia Internacional de Defesa do Estado / Direcção Geral de Segurança [International Police for Defense of the State / General Command for Security]

SCCIM - Serviços de Centralização e Coordenação de Informações de Moçambique [Mozambique Services for Centralisation and Coordination of Information]

\section{Primary sources:}

[Author?] (1960, February 16). General Government of Mozambique, Information from the Overseas Ministry. ANTT/SCCIM, no. 408, sheets 414-415, Lisbon.

[Author?] (1961). Communication of Service no. B-240. ANTT/SCCIM, no. 408, sheet 397, Lisbon.

[Author?] (1964, January 10). Extract from the Informative Bulletin no. 2/64, January 10, 1964, from the Circumscription of Milange. ANTT/SCCIM, no. 408, sheet 259, Lisbon.

[Author?] (1966, September 14). Seitas gentílicas no Concelho de Marromeu vistas por uma brigada desta policia [Native sects of the Council of Marromeu seen by a brigade of this police]. Secret Report of the PIDE, Delegation of Beira [Mozambique], no. 559/66-GAB. ANTT/PIDE-DGS, SC, Proc. 6037 CI (2), file 1, sheets 48-55, Lisbon.

[Author?] (1967a, February 27). A subversão no Distrito de Moçambique [Subversion in the District of Mozambique]. Information No. 239 - SC / CI (2). ANTT/PIDE-DGS, SC, Proc. 6037 CI (2), file 1, sheets 1719, Lisbon.

[Author?] (1967b, June 30). A problemática religiosa na provincial - O Islamismo [The religious problem in the province - Islamism]. ANTT/PIDE-DGS, Information no. 686-SC/CI(2), Proc. 6037, file 1, sheets 7-16, Lisbon. [Author?] (1968). Miscelânia sobre cultos religiosos [Miscellany on religious cults]. ANTT/SCCIM, no. 105, Supintrep no. 23, sheets 1-363, Lisbon.

Carvalhosa, M.S. (1958, March 4). Plano das escolas a construir na Província da Guiné [Plan of the schools to be built in the Province of Guinea] [Letter to the Minister of the Overseas]. AHU/ACL/UM/DGEDU/RCM/G50, Box 361, SR: G50/Missões - Assuntos das Dioceses - Prefeitura Apostólica da Guiné, sheet 4, Lisbon. 
Correia, Brigadier A.G. (1965, December 31). Annual report of Psychological action, Bissau. AHM, 44/1/844/4, Lisbon.

Cruz, Lieutenant-Colonel A.O. (1959, November 2). Information from the Commander of the Infantry Regiment of Nampula to the Chief of the General Staff of Mozambique's Military Command. ANTT/SCCIM, no. 408, sheets 419-420, Lisbon.

Monteiro, P. (1964, September 23). Report of the representative of the Cabinet of Political Affairs of the Overseas Ministry. AHU, Overseas Ministry/Cabinet of the Minister/Cabinet of the Political Affairs/160/File 6S, Lisbon.

Moreira, C. (1951, April 14). Speech. Diário das Sessões da Assembleia Nacional e Actas da Câmara Corporativa [Journal of hte National Assembly's Sessions and Proceedings of the Corporative Chamber], 98, $V$ Legislature, 848.

Rodrigues, L.A. (1959). Periodical Report of Counter-Intelligence no. 3/59. AHM, 39/11/592/362, 1959, Perintreps da Guiné (Periodical Reports of Intelligence and Counter-Intelligence of Guinea), Lisbon.

Sousa, Major F.L. (1954). Politics. In Mozambique Mohammedanism is more a political force than a religious one. [Military] Report of Information of Mozambique no. 262, $1^{\text {st }}$ Three Months of 1954, Secret, sheets 4-13. AHM, 39/11/585/262, 262, Lisbon.

Viegas, C. (1946, March). Speech. Diário das Sessões da Assembleia Nacional [Journal of the National Assembly’s Sessions], 39, IV Legislature, 661.

\section{Printed and secondary sources:}

Alpers, E.A. (1999). Islam in the service of colonialism? Portuguese strategy during the armed liberation struggle in Mozambique. Lusotopie, 1999, 165-184. Retrieved from http://www.lusotopie.sciencespobordeaux.fr/alpers.pdf.

André, P.-J. (1924). L'Islam Noir: Contribution à l'étude des confréries religieuses islamiques en Afrique Occidentale suivie d'une étude sur l'Islam au Dahomey [Black Islam: A contribution to the study of the Islamic religious brotherhoods in West Africa followed by a study on Islam at Dahomey]. Paris: Librairie Orientaliste Paul Geuthner.

Bastos, J. P. (1995). 'Portugal, minha princesa': Contribuição para uma antropologia pós-racionalista dos processos identitários e para o estudo do sistema de representações sociais identitárias dos portugueses ['Portugal, my princess': A contribution to a post-rationalist anthropology of the identity processes and to the study of Portuguese's social representations] (Unpublished doctoral dissertation). New University of lisbon, Lisbon, Portugal. 
Bastos, J.P. (2002). Portugal in Europe: Identity Strategies of the Portuguese. In L. Beltran, J. Maestro, \& L. Alo-Lee (Eds.), European peripheries in interaction: The Nordic countries and the Iberian Peninsula (pp. 223247). Alcalá: Universidad de Alcalá.

Bastos, J.P. (2003, March). 'The hidden meanings of culture, ethnicity and identity': Anthropology from a divergent point-of-view. Paper presented at a Lecture Series held at the University of California, Berkeley.

Bastos, S.P. (2008). Ambivalence and phantasm in the Portuguese colonial discourse production on Indians. Lusotopie, 15(1), 77-95.

Bastos, J.P., \& Bastos, S.P. (2005). 'Our colonizers were better than yours': Identity debates in Greater London. Journal of Ethnic and Migration Studies, 31(1), 79-98. doi: 10.1080/1369183042000305690.

Bonate, L. (2007a). Traditions and transitions: Islam and chiefship in Northern Mozambique ca. 1850-1974 (Doctoral dissertation, University of Cape Town, Republic of South Africa). Retrieved from http://www.asclibrary.nl/docs/315/822/315822449.pdf.

Bonate, L. (2007b). Roots of diversity in Mozambican Islam. Lusotopie, 14, 129-149.

Bonate, L. (2008, August). Colonial and post-colonial policies of Islam in Mozambique. Paper presented at the workshop on Changes in colonial and post-colonial governance of Islam: Continuities and ruptures, Leiden, Netherlands.

Cann, J.P. (2005). Counterinsurgency in Africa: The Portuguese way of war, 1961-1974. St. Petersburg, Florida: Hailer.

Castelo, C. (1998). 'O modo português de estar no mundo': O luso-tropicalismo e a ideologia colonial portuguesa, 1933-1961 ['The Portuguese way of being in the world': Lusotropicalism and the Portuguese colonial ideology, 1933-1961]. Porto: Afrontamento.

Correia, A.M. (1940). Da Raça e do espírito [Race and spirit]. Porto: Faculdade de Ciências do Porto - Instituto de Antropologia.

Cross, M. (1987). The political economy of colonial education: Mozambique, 1930-1975. Comparative Education Review, 31, 550-569.

Cruz, L.C. (1968). Alguns Aspectos da Subversão na Província Portuguesa da Guiné [Some aspects of subversion in the Portuguese province of Guinea]. Ultramar, 32, 125-147.

Dias, E.C. (2005). 'Islão negro’ versus 'verdadeiro Islão’: Dilema ou sintoma de persistente e injustificada discriminação dos muçulmanos africanos subsaarianos? ['Black Islam' vs. 'true Islam': Dilemma or symptom of a persistent and unjustified discrimination against Sub-Saharan Africans?]. Africana Studia, 8, 167-187.

Dias, J. (1956). Minorias étnicas nas províncias ultramarinas [Ethnic minorities in Overseas provinces]. Lisbon: Centro de Estudos Políticos e Sociais. 
Dias, J. (1958). Contactos de Cultura [Contacts of culture]. In Colóquios de Política Ultramarina Internacionalmente Relevante (pp. 55-82). Lisbon: Junta de Investigações do Ultramar - Centro de Estudos Políticos e Sociais.

Enes, A. (1946). Moçambique: Relatório apresentado ao governo [Mozambique: A report presented to the Government]. Lisbon: Agência Geral das Colónias. (Original work published 1893)

Felgas, H. (1965). Influência dos árabes na África actual [The influence of Arabs in present Africa]. Hors-texte of Revista Militar, July and August/September.

Franklin, A. (1956). A Ameaça islâmica na Guiné portuguesa [The Islamic threat in Portuguese Guinea]. Paper presented at the Fourth Congress of the União Nacional [National Union].

Freyre, G. (1983). Casa-Grande e senzala [Big House and senzala, translated in English as The master and the slaves, 1986]. Lisbon: Livros do Brasil. (Original work published 1933)

Froelich, J.C. (1962). Les musulmans d'Afrique Noire [Muslims from Black Africa]. Paris: Éditions de l'Orante. Garcia, F.P. (2000). Guiné 1963-1974: Os movimentos independentistas, o Islão e o poder português [Guinea 1963-1974: The independentist movements, Islam and the Portuguese power]. Porto/Lisbon: Universidade Portucalense e Comissão Portuguesa de História Militar.

Garcia, F.P. (2003). Moçambique: Análise global de uma guerra 1964/1974 [Mozambique: A global analysis of a war 1964/1974]. Lisbon: Prefácio.

Gonçalves, J.J. (1958). O Mundo arabo-islâmico e o Ultramar português [The Arab-Islamic world and Portuguese Overseas]. Lisbon: Ministério do Ultramar - Junta de Investigações do Ultramar, Centro de Estudos Políticos e Sociais.

Gonçalves, J.J. (1961). O Islamismo na Guiné Portuguesa (Ensaio Sociomissionológico) [Islamism in Portuguese Guinea]. Lisbon: Centro de Estudos Políticos e Sociais.

Harrison, C. (1988). France and Islam in West Africa, 1860-1960. Cambridge: Cambridge University Press.

Lima, M.H. (1964, December). Influência do Islão na Guiné portuguesa [The influence of Islam in Portuguese Guinea]. Paper presented at the First Congress of the Portuguese Communities, Lisbon, Portugal.

Macagno, L. (2002). Lusotropicalismo e nostalgia etnográfica: Jorge Dias entre Portugal e Moçambique [Lusotropicalism and ethnographic nostalgia: Jorge Dias between Portugal and Mozambique]. Afro-Ásia, 28, 97 124.

Macagno, L. (2006). Outros Muçulmanos: Islão e narrativas coloniais [Another Muslims: Islam and colonial narratives]. Lisbon: Imprensa de Ciências Sociais.

Martinez, P.S. (1970). O pensamento islâmico e a expansão socialista [Islamic thought and socialist expansion]. Hors-texte of Memórias da Academia das Ciências de Lisboa-Classe de Letras, 23, 29-46. 
Martins, O. (1978). O Brasil e as colónias portuguesas [Brazil and the Portuguese colonies]. Lisbon: Guimarães \& C. ${ }^{\text {a }}$ (Original work published 1880)

Mateus, D.C. (2004). A PIDE/DGS na Guerra Colonial (1961-1974) [The political police in the colonial war (1961-1974)]. Lisbon: Terramar.

Melo, A., Capela, J., Moita, L., \& Pereira, N.T. (Eds.). (1978). Colonialismo e lutas de libertação: 7 cadernos sobre a guerra colonial [Colonialism and liberation struggles: Seven books on the colonial war]. Porto: Afrontamento.

Monteiro, F.A. (1993). O Islão, o poder e a guerra (Moçambique 1964-1974) [Islam, power and war (Mozambique 1964-1974)]. Porto: Universidade Portucalense.

Monteil, V. (1971). L'Islam Noir [Black Islam]. Paris: Seuil.

Mota, A.T. (1954), Guiné Portuguesa [Portuguese Guinea] (Vol. 1). Lisbon: Agência Geral do Ultramar.

Pimentel, I.F. (2007). A história da PIDE [History of the International Police for the Defense of the State]. Lisbon: Círculo de Leitores.

Rego, A.S., Silva, M.C., \& Gonçalves, J.J. (1960). Missão para o estudo da missionologia africana: Relatório da campanha de 1959 [Mission for the study of African missionology: 1959 report]. Lisbon: Centro de Estudos Políticos e Sociais da Junta de Investigações do Ultramar.

Rego, L. (1959). Pátria morena: À vista da maior epopeia lusíada [Dark fatherland: On the edge of a major Portuguese epic]. Macieira de Cambra: Edições da LAIN.

Rego, L. (1966). A 'Declaração sobre a liberdade religiosa' no tempo e espaço da Nação Portuguesa [The 'Declaration on religious freedom' in the time and space of the Portuguese Nation]. Braga: Edições da LAIN Leigos Apóstolos da Integração Nacional.

Rego, L. (n.d.). Apocalipse de Sagres [Apocalypse of Sagres]. Braga: Edições da LAIN - Leigos Apóstolos da Integração Nacional.

Rodrigues, S. (1948). Os maometanos no futuro da Guiné Portuguesa [The Mohammedans in the future of Portuguese Guinea]. Boletim Cultural da Guiné Portuguesa, 9(3), 219-231.

Santos, B.S. (2002). Entre Prospero e Caliban: Colonialismo, pós-colonialismo e inter-identidade [Between Prospero and Caliban: Colonialism, post-colonialism, and inter-identity]. In M.I. Ramalho \& A.S. Ribeiro (Eds.), Entre ser e estar: Raízes, percursos e discursos da identidade [Between being and staying: Roots, trajectories and discourses of identity] (pp. 23-85). Porto: Afrontamento.

Telo, A.J. (1994). Economia e império no Portugal contemporâneo [Economy and Empire in the contemporary Portugal]. Lisbon: Edições Cosmos. 
Triaud, J.-L. (2006). Politiques musulmanes de la France en Afrique subsaharienne à l'époque coloniale. In P.-J. Luizard (Ed.), Le choc colonial et l'islam. Les politiques religieuses des puissances coloniales en terres d'islam [Colonial clash and Islam: The religious politics of colonial powers in Islamic lands] (pp. 271-282). Paris: La Découverte.

Vakil, A. (2004). Pensar o Islão: Questões coloniais, interrogações pós-coloniais [Thinking Islam: Colonial questions, post-colonial interrogations]. Revista Crítica de Ciências Sociais, 69, 17-52.

Vieira, G.B. (1971). Contribuição dos Muçulmanos Portugueses da Guiné para a Estabilidade Nacional [Contribution of Portuguese Muslims to National stability]. Revista Militar, 10, 595-613.

West, H. (2006). Invertendo a bossa do camelo. Jorge Dias, a sua mulher, o seu intérprete e eu [Turning the camel's hump upside down. Jorge Dias, his wife, his translator, and I]. In M.R. Sanches (Ed.), 'Portugal não é um país pequeno': Contar o 'império' na pós-colonialidade ['Portugal is not a small country': Narrating the 'Empire' in post-coloniality] (pp. 141-190). Lisbon: Livros Cotovia. 